\title{
FAULT AS AN ELEMENT OF DIVORCE JURISDICTION
}

\author{
HENRY L. MGCLINTOCK
}

Before the decision of the United States Supreme Court in the case of Haddock v. Haddock ${ }^{1}$ was handed down in 1906, there was a quite general agreement among American courts that divorce was a proceeding in rem, the res being the marriage status, and that a state in which either party to the relation was domiciled had jurisdiction to dissolve the marriage, even though it acquired no jurisdiction over the person of the other party. ${ }^{2}$ The leading case in support of this doctrine, Ditson $v$. Ditson, ${ }^{3}$ had been followed in many other jurisdictions and apparently had been approved by the United States Supreme Court. ${ }^{4}$ The extent to which this doctrine was modified by the decision in Haddock v. Haddock was a matter of controversy at the time that case was decided, ${ }^{5}$ has been more or less debated since that time, ${ }^{6}$ and is still a question as to which eminent authorities on the subject of conflict of laws differ. ${ }^{7}$ If that decision is to be accepted as controlling the determination of divorce jurisdiction in the conflict of laws sense, that is, jurisdiction to grant a divorce which other states ought, according to the common law principles of the conflict of laws, to recognize as valid, then it must be conceded that domicile of one party is not alone a sufficient basis for jurisdiction. But there is no general agreement either as to the additional element or elements that must be present, or as to the theory which requires the presence of the other elements.

If Haddock $v$. Haddock stood alone it could be very persua-

\footnotetext{
1201 U. S. 562, 26 Sup. Ct. 525 (1906).

21 Bishop, Marriage, Divorce and Separation (1891) §§ 136-152.

34 R. I. 87 (1856).

${ }^{4}$ Cheever v. Wilson, 9 Wall. 108 (1869); Atherton v. Atherton, 181 U. S. 155, 21 Sup. Ct. 544 (1901).

5 Beale, Constitutional Protection for Divorce (1906) 19 HARv. L. REv. 586; Bigelow, Two Recent Cases on Inter-state Marital Relations (1906) 18 GREEN BAG 348; Schofield, Doctrine of Haddock v. Haddock (1906) 1 ILL. L. REv. 219; Thurber, Foreign Divorce Decrees in New Yorl: (1907) 10 BENCH AND BAR 82.

- Berger, Extra-Territorial Effect of Decree for Divorce on Constructive Service (1911) 45 AM. LAW REv. 564; Lewis, Divorce and the Fcdcral Constitution (1915) 49 AM. LAW Rev. 852; Peaslee, Ex Parte Divorce (1915) 28 HARV. L. Rev. 457.

7 Beale, Haddock Revisited (1926) 39 HARv. L. REv. 417; Goodnich, CoNFLICT OF LAWS (1927) § 127.
} 
sively argued that it established the principle that both domicile of one spouse within the state and personal jurisdiction over the other were essential to give to the court of one state jurisdiction to render a decree of divorce which was entitled under the Constitution of the United States to full faith and credit. But any explanation of the Haddock case must be consistent with Atherton $v$. Atherton, in which it was held that a divorce decree rendered in a suit in which the defendant was not personally served and did not appear was nevertheless entitled to full faith and credit. The view of $M I r$. Justice Holmes in his dissenting opinion in Haddock $v$. Haddock, in which some of the commentators on that case concurred, that Atherton v. Atherton was thereby overruled in effect, must be discarded since the court, in a unanimous opinion in the case of Thompson $v$. Thompson, ${ }^{9}$ treated the two cases as distinguishable and followed the decision of Atherton $v$. Atherton. Any explanation of Haddock $v$. Haddock must, therefore, be consistent with the other two cases to be sustainable on authority.

One theory which seems to be receiving increased recognition at the present time is that the fault of the non-resident spouse, which justifies the spouse domiciled within the state of the forum in living apart from the other, is sufficient to give jurisdiction. ${ }^{20}$ Since this theory has been incorporated in the tentative draft of the Restatement of the Conflict of Laws, ${ }^{11}$ an examination of the basis for it in the decisions and of the practical effects of its adoption may be justified.

Some of the statements of Mr. Justice White, who wrote the opinion of the majority in Haddock v. Haddock, tend to support this theory. In stating the sixth and seventh of the propositions which the court regards as settled by prior decisions and on which it proposes to base its decision, the rules that the wife may acquire a separate domicile if the husband's fault justifies her in living apart from him, and may not acquire such domicile if the separation is due to her fault, are recognized as determining whether the state in which the husband sues for divorce is the state where both are domiciled so as to have jurisdiction under the fifth proposition.12 In answering the contention that divorce was a proceeding in rem and the res was in the state where the husband was domiciled the opinion says:

"As the husband, after wongfully abandoning the wife in New York, never established a matrimonial domicile in Con-

8 Supra note 4.

9226 U. S. 551, 33 Sup. Ct. 129 (1913).

10 Beale, op. cit. supra note 7 , at 420 .

11 American Law Institute, Restatemient on the Conflict of Laws, No. 2 (1926) § 118 (b).

${ }^{12}$ Supra note 1, at 570-572, 26 Sup. Ct. at 527, 528. 
necticut, it cannot be said that he took with him that marital relation from which he fled to Connecticut." ${ }^{13}$

But the statement of facts contained in the opinion does not warrant this language unless we treat the finding of the court which is asked to extend faith and credit to the judgment of a sister state as conclusive of jurisdictional facts. The opinion states that the parties were married in New York in 1868 and that the wife brought this action in that state in 1899 for separation from bed and board and for alimony on the ground of the husband's desertion; that the answer alleged that the separation was by mutual consent and that the husband had in 1881 procured a divorce in Connecticut where he was then in fact domiciled; that at the trial before the referee the judgment roll in the Connecticut suit for divorce was excluded from evidence and thereafter the referee found that the husband without justifiable cause abandoned the wife. ${ }^{14}$ In the dissenting opinion of Mr. Justice Brown it is stated that the complaint in the Connecticut suit alleged a willful desertion by the wife and the court found that to be a fact.15

In both Atherton $v$. Atherton and Thompson $v$. Thompson the wife left the state in which she had been living with her husband and brought suit against him in another jurisdiction. In both cases the husband set up in defense a divorce obtained by him in the state of his domicile, which remained where he and the wife had lived together. In both cases the court before which the wife's suit was pending refused recognition to the decree relied on by the husband and found that the wife was justified in leaving the husband. The United States Supreme Court held that the decrees were entitled to full faith and credit and reversed the decisions for the respective wives.

If we are to conclude that there is authority for the proposition that jurisdiction to render a binding divorce decree after only constructive service of a non-resident defendant depends on whether the separation is due to the fault of the plaintiff or defendant, we must find some justification for accepting in Haddock $v$. Haddock the finding as to fault which was made by the court which was asked to extend credit to a prior foreign decree and for accepting in the other two cases the findings made by the courts which rendered the prior decrees. If we disregard the allegation of Haddock's answer that the separation was by mutual consent, which allegation is not referred to in any of the opinions, the only difference in the facts in these cases is that in the Haddock case the husband had left the wife,

13 Ibid. 577, 26 Sup. Ct. at 530.

14 Ibid. 564, 565, 26 Sup. Ct. at 525.

15 Ibid. 609, 26 Sup. Ct. at 542. 
and in the other two cases the wives had left the husbands. Of course, if the wives had deserted their husbands, the ordinary rule is that they could not acquire separate domiciles and, therefore, the courts in which the husbands sued had jurisdiction over the entire res. But it is equally true that if Mirs. Haddock deserted her husband by refusing to accompany him into Connecticut, as the Connecticut court found, her domicile followed his and Connecticut had complete jurisdiction. We are still no nearer to the solution of the question as to which court's finding on the issue of fault is to be accepted. On principle, it would seem that if fault is a jurisdictional fact, the Supreme Court is the ultimate tribunal to determine that fact, but in none of the three decisions is there any intimation that it has made such a determination, nor do the records, as given in the reports, permit such a determination.

A suggestion has been made that a finding of the court which rendered the earlier decree as to a jurisdictional fact is conclusive where there is substantial evidence to sustain it, and the fact that the wife left the husband in the state where they had been living together was sufficient in Athcrton v. Atherton and Thompson $v$. Thompson to support a finding that the fault was hers, while there was no substantial evidence to support the finding of the Connecticut court that Mrs. Haddock had deserted her husband.18 The only case ${ }^{17}$ cited for the major premise dealt with an attack on the jurisdiction of a bankruptcy court over a corporation based on the claim that the president of the corporation was not authorized to file the petition in involuntary bankruptcy. The court held that that question was one which the statute gave the bankruptcy court power to determine so that its determination, if supported by any evidence, was conclusive. The determination of the extent of a court's jurisdiction under a particular statute depends on principles entirely different from those which determine the jurisdiction of the courts of a state to render a judgment which will be entitled to full faith and credit. The United States Supreme Court has uniformly held that a court which is asked to give credit to the judgment of a sister state may determine whether the facts essential to the jurisdiction of the other State existed and cannot be concluded by any recitals in the record of the proceedings in the other state. ${ }^{18}$

In Thompson $v$. Thompson the court said:

"In the Atherton Case the matrimonial domicile was in Kentucky. . . . . In the Haddock Case, the husband and wife were

\footnotetext{
${ }^{16}$ Thurber, loc. cit. supra note 5.

${ }_{17}$ New Lamp Chimney Co. v. Ansonia Brass and Copper Co., 91 U. S. 656 (1875).

182 BLACK, JUDGMENTS (2d ed. 1902) $\S 901$ and cases cited.
} 
domiciled in New York and the husband left her there, and, after some years, acquired a domicile in Connecticut, and obtained in that state, and in accordance with its laws, a judgment of divorce, based upon constructive, and not actual, service of process on the wife. . . . The New York court refused to give credit to the Connecticut judgment, and this court held there was no violation of the full faith and credit clause in the refusal, and this because there was not at any time a matrimonial domicile in the State of Connecticut, and therefore the res-the marriage status-was not within the sweep of the judicial power of that state." 19

In the opinion in the Haddock case, the court, in distinguishing the Atherton case, says :

"The decision in that case, however, as we have previously said, was expressly placed upon the ground of matrimonial domicil." ${ }^{20}$

None of the three opinions undertakes to state what is meant by "matrimonial domicil" which is thus held to be an element which gives complete jurisdiction to the state of domicile of only one of the spouses. Considering the facts which were stressed in distinguishing the Haddock case from the other two, it would appear that by "matrimonial domicil" the court meant the place where the parties last lived together as husband and wife, and where they were legally domiciled while so living together. This is also the meaning attributed to the term by most commentators on the Haddock case, ${ }^{21}$ and most of the few courts which have considered it.22 But suppose that both parties, after the separation, have permanently left the jurisdiction in which they last lived together; is there then any matrimonial domicile? The Texas Court of Civil Appeals in Montmorency $v$. Montmorency,,$^{23}$ has held that the innocent party in such a case can take the matrimonial domicile to the new domicile of that party. If the innocent party is the husband, the question would be unimportant so long as we adhere to the rule that the wife's domicile follows that of the husband unless he gives her cause

19 Supra note 9, at 561, 562, 33 Sup. Ct. at 131.

${ }^{20}$ Supra note 1, at 584, 26 Sup. Ct. at 533.

21 Goodrich, Matrimonial Domicile (1917) 27 Yale LaW Journat 49, 64; Lewis, op. cit. supra note 6, at 856; Schofield, op. cit. supra note 5, at 232; Bigelow, op. cit: supra note 5, at 350 . Professor Beale originally understood the term to have this meaning. See Beale, op. cit. supra noto 5, at 587 .

22 De Bouchel v. Candler, 296 Fed. 482 (N. D. Ga. 1924); Callahan v. Callahan, 65 Misc. 172, 121 N. Y. Supp. 39 (Sup. Ct. 1909); State ex rol. Aldrach v. Morse, 31 Utah 213, 87 Pac. 705 (1906).

23139 S. W. 1168 (Tex. Civ. App. 1911). This case was approved by dictum in Parker v. Parker, 222 Fed. 186, 190 (C. C. A. 5th, 1015). It is also approved by Professor Beale. Op. cit. supra note 7, at 426, n. 30. 
for leaving him, ${ }^{24}$ for then the jurisdiction where he was domiciled would be the domicile of both and its courts could render a divorce decree binding everywhere. But if the husband deserts the wife, he may, nevertheless, acquire a new domicile for himself, though it does not become her domicile. That was the situation before the Texas court in the Montmorcncy case. If the fault of the husband were not desertion but such cruelty as would justify the wife in leaving him, it would seem that she might then, too, take the matrimonial domicile with her under the reasoning of that case. But that was the situation the New York court found to exist in Atherton v. Atherton and yet the United States Supreme Court held, without determining the question of fault, that the matrimonial domocile was in Kentucky, where the husband remained, and not in New York, to which state the wife had gone.

But it is not contended that courts in general have expressly adopted the theory that fault is an element in determining divorce jurisdiction, the argument is rather that the actual results of most of the decisions are consistent with that theory, ${ }^{25}$ the theory is sound in principle, and its express adoption would straighten out the tangles in our law of recognition of divorce..$^{a}$ The theory is justified in principle by the argument that the interest of the non-resident spouse cannot be affected unless that spouse has been personally served or has submitted to the juris-

24 It is doubtful just how general today is adherence to the rule that a wife who lives apart from her husband because of her own fault cannot acquire a separate domicile. See AMrerican LAW INST. Conflict of Latrs Restatement No. 1 (1925) $\$ 30 \mathrm{n}$. In Williamson v. Osenton, $232 \mathrm{U}$. S. 619, 625, 34 Sup. Ct. 442, 443 (1914), MIr. Justice Holmes says: "The only reason that could be offered for not recognizing the fact of the plaintifr's [wife's] actual change [of domicile], if justified, is the now vanishing fiction of identity of person." In Saperstone v. Saperstone, 131 N. Y. Supp. 241 (Sup. Ct. 1911), the court held that a Russian wife who continued her journey to this country after her husband had been rejected at the port of embarkation, intending to separate permanently from him and live here, had acquired a domicile here so that a Russian rabbi had no jurisdiction to grant her a divorce. See, also, in the explanatory note to the restatement above eited, by the director of the Institute, on p. 4, other suggested wordings for sec. 30 which make actual separation the only prerequisite to the wife's power to acquire a separate domicile. Kan. Rev. Stat. (1923) $\S 60-1503$ and N. Y. Civ. Prac. Act $\S 1166$, each provide that a married woman living in the state is a resident thereof, though her husband lives elsewhere.

${ }^{25}$ This is true only on the assumption that the finding of one court or the other on the issue of fault as affecting the merits is a finding which we can accept as determining a jurisdictional issue.

26 Beale, op. cit. supra note 7 , at $421,425,429$. This article seems to have been written as the reporter's justification for the adoption of sec.

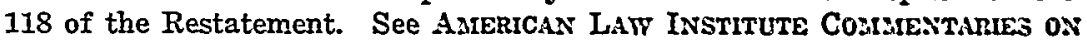
CoNFlict of Latws, Restatement No. 2 (1926) 30-32. 
diction of the court. That submission may be by appearance or by misconduct. ${ }^{27}$ But it is clearly a fiction to say that a husband who deserts his wife in New York, where the law will give her only a separation for such misconduct on his part, thereby submits his interest in the marriage relation to the jurisdiction of the courts of Connecticut to which the wife may change her domicile without the knowledge, or against the will, of the husband. It may be that a proper balancing of the interests affected justifies us in recognizing jurisdiction in the Connecticut court under those circumstances to terminate his interest in the relation, but we cannot say that he has, in any real sense, submitted his interest to the jurisdiction of that state.

One of the practical gains which will follow the adoption of this theory of divorce jurisdiction is that the wife will be put upon an absolute equality with her husband so far as a right to a divorce is concerned. ${ }^{28}$ It is true that, so long as we do not recognize the wife's right to acquire a new domicile separate from that of her husband unless his fault justifies her in living apart from him, she cannot obtain a divorce in a state where she is actually residing apart from her husband unless she can show that the separation was not due to her fault. But if the tendency of the courts to enlarge the power to acquire a separate domicile continues, ${ }^{29}$ this inequality will soon disappear if it has not already disappeared. ${ }^{30}$

But the need for uniformity in recognition of divorce decrees far outweighs any other practical consideration in dealing with this subject. The serious, often tragic, consequences of diverse rulings upon this question have been universally recognized. What appear to be the probabilities that the principles of divorce jurisdiction laid down in the Restatement will meet with such general acceptance as to eliminate, or even lessen the discordant views of the several states on this question? The Massachusetts court has suggested that the adoption of the principles laid down by the federal Supreme Court as the basis for the exercise of inter-state comity will bring about a closer approach to unity of decision among the several states, ${ }^{31}$ but before those principles can be generally adopted, there must be a general agreement as to what they are, and certainly there is, as yet, no agreement that jurisdiction depends on the fault of the non-

\footnotetext{
${ }^{27}$ Beale, op. cit. supra note 7 , at 425 .

28 Ibid. 429.

29 See supra note 24.

${ }^{30}$ Even New York has recognized a divorce granted ex parte to a wife in a state where she was living apart from her husband without determining whose fault led to the separation. Hubbard v. Hubbard, 228 N. Y. 81, 126 N. E. 508 (1920).

31 See Perkins v. Perkins, 225 Mass. $82,87,113$ N. E. 841,843 (1916).
} 
resident spouse. ${ }^{32}$ On the contrary, Thompson $v$. Thompson furnishes strong authority for arguing that the federal Supreme Court does not so hold, even if we concede that such a holding might be deduced from the language of Haddocle v. Haddock.

There is little evidence as yet that courts which before the decision of Haddock v. Haddock recognized foreign divorces in all cases where one spouse was domiciled bona fide in the state where. the decree was rendered are manifesting any tendency now to refuse that recognition. In the MIassachusetts case last referred to, recognition was refused where the iIassachusetts court found that the wife was not at fault, and she had had no notice of the proceedings by which her erring husband obtained a divorce in another jurisdiction where he was then domiciled bona fide. The Texas Court of Civil Appeals apparently has adopted the rule of Haddock v. Haddock as the test of jurisdiction to grant divorce. ${ }^{33}$ The Utah court found it unnecessary to decide whether its jurisdiction was limited to cases where its decree was entitled to full faith and credit, for it found the matrimonial domicile to have been in Utah. ${ }^{\text {sis }}$ In other cases the courts have apparently been unaffected by the Haddocle case except in so far as it has compelled them to extend recognition which they formerly refused to extend. ${ }^{35}$ In at least one state a statute was enacted after the decision of Haddock v. Haddock validating divorce decrees rendered in any state in conformity to the law thereof. 38

In view of these cases, it requires a high degree of optimism to entertain much hope that the Restatement will induce a uniform practice in all jurisdictions to refuse recognition to divorce decrees unless such recognition is required under the Haddock case as there interpreted.

But even if all our courts should accept the principle that jurisdiction to grant a divorce on constructive service depends upon the fault of the non-resident, non-appearing spouse, we should still be far from the desired goal of uniform recognition

${ }^{32}$ Supra notes $21,22$.

33 Miontmorency v. Miontmorency, supra note 23.

34 State ex rel. Aldrach v. Morse, supra note 22.

35 GoodRICH, op. cit. supra note 7, at 296, and cases cited in n. 32 . The Georgia case of Solomon v. Solomon cited in that note as rcquiring actual lnowledge of the suit by the absent defendant followed without argument the case of Miatthews v. MIatthews, 139 Ga. 123, 76 S. E. 855 (1912), where the refusal to recognize the Alabama decree involved was based on the ground of the wife's fraud in claiming a domicile in Alabama and in stating her husband's whereabouts were unknown, as a result of which he was not given the personal notice of the suit required by the Alabama law.

36 Kan. Laws 1907, c. 184, § 1; MIcCormich v. MrcCormick, 82 Kan. 31, 107 Pac. 546 (1910). A similar statute of Indiana was enacted before the Haddock decision. Hilbish v. Hattle, 145 Ind. 59, 44 N. E. 20 (1896). 
of divorces. As an issue of fact, the question of fault is one difficult to determine. It is probable that the case does not often arise where the fault is all one one side. In many cases it is almost impossible to say who is most at fault even if all the acts of the parties are known. It would not be surprising to find that the courts will differ as to this question of fault. They did differ in Atherton v. Atherton, Haddock v. Haddock, and Thompson $v$. Thompson. The issue of fault, like any other jurisdictional fact, could then only be determined by the United States Supreme Court. Surely we ought to hesitate before we adopt a rule which would impose on that court the obligation of determining such a difficult issue of fact whenever it is claimed that a state court has refused full faith and credit to a foreign divorce granted without jurisdiction over the person of one of the parties. Such cases would probably be more frequent than they have been in the past, since it is suggested that, to insure uniformity, recognition be refused except where it is required under the suggested rule. ${ }^{37}$ Certainly it would seem to be contrary to wise social engineering to occupy the time of that court with the decision of mere issues of fact unless such a burden must be imposed to avoid the evil of diverse holdings in different states as to the validity of a divorce.

Furthermore, the issue of recognition of divorce must often be determined after the death of one ${ }^{38}$ or both ${ }^{30}$ of the parties to the marriage relationship. In these cases it will generally be impossible for any court to determine the issue of fault unless the examination is limited to the more or less public conduct of the parties, and it is obvious that a finding based on an examination so limited would frequently be contrary to the actual facts. It is still considered good form in most social groups for a husband and wife to treat each other with courtesy in public, whatever happens in private. Merely to learn which spouse committed the first public breach of the marriage relation gives no clue as to the real fault of the parties, except, probably, where the breach is an act of adultery.

But not only does the suggested theory of jurisdiction require the solution of difficult questions of fact; it also requires the ascertainment of principles of law for the determination of which there seems to be no practical machinery available. What law is to determine the degree of matrimonial fault which bars a spouse from objecting to the other's acquisition of a separate

${ }^{37}$ Beale, op. cit. supra note 7, at 428.

${ }^{38}$ E.g., Andrews v. Andrews, 188 U. S. 14, 23 Sup. Ct. 237 (1903); Hilbish v. Hattle, supra note 36 ; Howard v. Strode, 242 Mo. 210, 146 S. W. 792 (1912); Hubbard v. Hubbard, supra note 30; Douglas v. Teller, 53 Wash. 695, 102 Pac. 761 (1909).

${ }^{39}$ E.g., Maynard v. Hill, 125 U. S. 190, 8 Sup. Ct. 723 (1888). 
home? It is probably safe to assume that it is not intended that the fault shall necessarily be sufficient to entitle the other spouse to an absolute divorce. A fault which is ground for divorce from bed and board or for judicial separation would seem to satisfy the requirement. If we should limit the meaning of "fault" to desertion, we should still be confronted with conflicting state rules as to what constitutes desertion. ${ }^{* 0}$ The obvious answer to this objection is that if fault is an element of jurisdiction essential to entitle a divorce decree to full faith and credit under the federal constitution, it is for the United States Supreme Court to determine the legal content of the term. But on what basis is the court to make that determination? At the time the Constitution was adopted there was no common law as to jurisdiction to divorce, and certainly none as to jurisdiction where the spouses had separate domiciles, for the right of the wife to acquire a separate domicile was not recognized until much later. The difficulty cannot be met by legislation, for no legislative body has power to act. The state legislatures, of course, cannot determine what gives jurisdiction in the federal sense. Congress has been given no power to determine what judgments are entitled to full faith and credit, it can only prescribe the method of authentication and the effect of such judgments as are within the constitution. ${ }^{\Delta 1}$ Without a constitutional amendment, the only way to determine the legal content of the term "fault" would be by the Supreme Court's applying its conception of the "general law" of marital relationships to the various concrete factual situations presented by the successive cases brought before it. In the twenty years since Haddocls v. Haddock was decided there has been only one case taken to the Supreme Court involving the problem of recognition of foreign divorce decrees. Even if the number of cases were increased twenty-fold by the adoption of the suggested jurisdictional test, a result to be deprecated rather than desired, it is manifest that we should have to wait a long time before we had any clear idea as to what "fault" meant." It is probable that our social views as to the causes for divorce would change more rapidly than this cumbersome process could at all adequately delimit the scope of the term as we understand it today. If the development of the law by the judicial process is too slow to keep pace with changing social and economic views on questions that are daily presented to our courts, how can we expect it to function ade-

10 KeEzer, IIARRiage aNd Divonce (2d ed. 1923) c. 21.

\&1 U. S. CoNST., Art. IV, § 1 .

42 It should be remembered that on this question the lower federal courts could not aid the Supreme Court in working out the legal content of the term "fault." Denial of full faith and credit is not ground for removal from a state court to a lower federal court. 
quately in a field where the social viewpoint is changing as rapidly as it has been in recent years with reference to divorce, and where only one case has been presented in twenty years in which the law can be authoritatively declared? To hope that in such a situation we could achieve uniformity of decision as to recognition of foreign divorces is to disregard all the lessons of recent legal experience.

Not only would the proposed theory fail to give us uniformity of recognition of foreign divorces, but there is great reason to fear that it would result in greater divergence than exists today. The great majority of our states prior to the decision of Haddock v. Haddock recognized any foreign divorce where one of the parties was bona fide domiciled in the state which rendered the decree. ${ }^{43}$ The only states in which a tendency has been observed to restrict recognition since that case was decided are Massachusetts ${ }^{44}$ and Texas. ${ }^{45}$ If other considerations were equal it would seem that there would be more probability of securing a uniform recognition of the view held by the majority of courts rather than the view of the minority. But the minority courts do not agree among themselves as to the rule they will follow. The situation is that we have a majority of the courts agreed upon one rule, and a small minority rejecting that rule in whole or in part and each adopting a different rule for its guidance.40 There is no reason to believe that any of these courts would be more willing to accept the rule of another minority court than they are to accept that of the majority.

In a restatement of the conflict of laws there is no need to

43 Beale, op. cit. supra note 5, at 587; Goodrich, op. cit. supra note 7, at 295, 296.

44 Perkins v. Perkins, supra note 31 .

${ }^{45}$ In Parker v. Parker, supra note 23 , the court determined that such was the result of the Texas cases which had determined the extent of their own jurisdiction to grant divorce in accordance with the principles of Haddock v. Haddock.

46 For example, Perkins v. Perkins, supra note 44, interprets the Haddock case as requiring that the parties have lived together in the stato where the decree was rendered; Montmorency v. Montmorency, suprat note 23, interprets it as vesting jurisdiction in the state where the innocent party was domiciled. New York has apparently adopted the view that her public policy forbids recognition of a divorce affecting her own citizens except for adultery. Consequently, whenever she can, she refuses such recognition. Hubbard v. Hubbard, supra note 30. Though she will recognize a foreign divorce granted in a jurisdiction where both parties tomporarily resided, and where the ground of divorce was adultery, notwithstanding the fact that both parties were at the time legally domiciled in New York. Gould v. Gould, 235 N. Y. 14, 138 N. E. 490 (1923). In the recent case of Dean v. Dean, 241 N. Y. 240,149 N. E. 844 (1925), Judge Cardozo suggested a different basis for the recognition of foreign decrees, but it is not certain that a majority of the court agreed with him. 
reconcile the position taken with Haddock v. Haddock. That case deals with a question of constitutional law, and it expressly refuses to decide what recognition each state should give a foreign divorce decree. ${ }^{47}$ The latter is the proper question for conflict of laws, and while, ordinarily, the constitution requires full faith and credit to be given to a judgment of a sister state if the principles of conflict of laws require recognition of a foreign judgment under similar circumstances, it does not necessarily follow that an interpretation of the constitutional clause by the United States Supreme Court, which eliminates from the operation of that clause cases entitled to recognition under the principles of the conflict of laws, requires us to narrow the scope of those principles to correspond.

It would seem that there ought to be no dissent from the proposition that courts should recognize as valid all foreign judgments rendered under circumstances which they would consider sufficient to give themselves jurisdiction under the common law. ${ }^{48}$ In Haddock $v$. Haddock it is said that all of the states with the possible exception of Rhode Island recognize the power to decree divorce based on mere domicile of the plaintiff, although the decree will be valid only within the state where rendered. ${ }^{49}$ If we accept this as true, then the statutes of the various states prescribing the conditions under which the divorce will be granted, generally by fixing the time during which the plaintiff must have resided within the state before beginning suit, $^{50}$ are limitations on existing jurisdiction. In view of this unanimity it would seem to be plain that the only basis on which we can reasonably hope to secure an agreement as to recognition of foreign divorce decrees is this basis on which the states are so well agreed that the jurisdiction of each to grant a divorce rests.

It is, of course, apparent that the most frequent cases under the existing situation where parties find themselves divorced in

${ }^{47}$ Supra note 1 , at 605,26 Sup. Ct. at 542.

18 Situations where a binding statute requires a court to exercise jurisdiction which it would otherwise consider did not belong to it are excluded. Cf. Schibsby v. Westenholz, L. R. 6 Q. B. 155 (1870).

49 Supra note 1 , at 603,26 Sup. Ct. at 541.

so See summary of divorce statutes in KEEZER, op. cit. supra note 40, at 651-742. Missachusetts alone requires that the parties shall have lived together in the state. N. Y. Civ. Prac. Act $\$ 1147$ requires either that both parties be residents; that they were married within the state; that plaintiff resided in the state when the offense was committed and when the action was commenced; or that the offense was committed in the state and the injured party was a resident when the action was commenced. It is obvious that under these provisions divorce decrees could be rendered in many cases which were not entitled to full faith and credit under any of the principles stated in the Haddock case. 
one state and married in another arise where the divergent views are not those of two different states as to the recognition of a divorce granted by a third state, ${ }^{51}$ but where a divorce recognized as valid in the state where it is granted is refused recognition in another state. Therefore, to meet the greatest need for uniformity we must either adopt as the rule of conflict of laws the rule of jurisdiction, or, after securing agreement as to a different rule for the conflict of laws, secure also a substitution of that rule for the rule of jurisdiction now so nearly universally accepted. The only possibility of such a substitution is by the authority of the United States Supreme Court. But that court has frequently recognized the local validity of divorces obtained in accordance with the rule that domicile of only one party is necessary, and it expressly reiterated that position in Haddock $v$. Haddock. ${ }^{52}$ It is true that the statement there was dictum in the sense that the court was not called upon to decide whether the Connecticut decree was valid in Connecticut, but it was not obiter, for it was the basis on which the court distinguished from the case at bar a previous case ${ }^{63}$ which it not only did not overrule, but expressly approved as still sound law. Certainly that statement will prevent the Haddock case from being very effective in inducing the states to abandon their accepted views as to jurisdiction to grant a divorce which will be valid within their own borders. Most of them will feel bound by their statutes, previously held valid, until there is an authoritative decision that those statutes violate the federal Constitution.

The objection that the majority view, if generally adopted, will lead to a race of diligence in different states is not sufficient to outweigh the advantage it possesses of securing uniformity of holding as to the validity of divorce."54 The objection is not

51 It is safe to assume that in this situation most states would follow Ball v. Cross, 231 N. Y. 329, 132 N. E. 106 (1921), in holding that tho decision of the state of the domicile of the defendant in the divorce proceedings as to the status resulting from the divorce would be followed elsewhere. $C f$. Armitage v. Attorney General [1906] Prob. 135.

52 Supra note 1, at 569, 26 Sup. Ct. at 527.

53 Maynard v. Hill, supra note 39.

54 Haddock v. Haddock, supra note 1, at 580, 26 Sup. Ct. at 532. The court here is manifestly concerned about the general situation, not the particular case. Mr. and Mrs. Haddock had separated immediately after the marriage ceremony by consent, according to his statement which seems to accord with the other facts, and had never lived together. Thirteon years after the ceremony the Connecticut divorce decree was rendered, and eighteen years later Mrs. Haddock brought her suit in New York. By no stretch of the imagination could that be called a "race" of diligence. Very much of the language of the prevailing opinion indicates the decision was based on the general feeling of opposition to the practice of seeking states with lax divorce laws, a practice which it seems could have been much 
so serious as appears on the surface. In very few of the cases where one spouse has sought another state solely to obtain a divorce would there be much difficulty in establishing that there was no domicile in that state and, therefore, no jurisdiction to render a decree which is valid where it was rendered or anywhere else. While determining the issue of domicile before the decree is granted may involve a difficult decision as to intent, the intent is generally manifest before the question of foreign recognition of the decree arises. If it could be impressed upon those seeking divorce that the decree is worthless, though it may bear the seal of an established court, unless there was a bona fide domicile, as distinguished from a mere compliance with certain technical requirements to show residence, the practice of selecting a favorable jurisdiction to obtain divorce would be greatly checked if not entirely stopped. But when we see parties accepting and paying for decrees rendered by a foreign court which has no semblance of jurisdiction, it is, perhaps, too much to hope they can be convinced that a decree of any court is not sufficient. However, if the courts are agreed as to what is a valid decree, it may be that in time the rule so agreed upon will become part of the common knowledge of the people.

It would seem that the weight of authority on the conflict of laws question, the commonly accepted theory of divorce suits, and practical considerations all unite in sustaining the principle that domicile of one spouse gives jurisdiction to divorce. It may well be that due process of law requires some better notice than mere publication of summons. If we accept the proposition that it is also a principle of the conflict of laws that judicial jurisdiction over a status cannot be exercised unless a method of notification is employed which is reasonably calculated to give interested persons knowledge of the proceeding and an opportunity to be heard, ${ }^{55}$ it would seem to follow that publication would be insufficient.so Where the res within the jurisdiction is tangible, there is reason to hold that the owner must take notice of proceedings where that res is situated, but where it is a status which may be affected by decree in any jurisdiction

better dealt with by a recognition, as in Andrews v. Andrews, supre note 38 , that such decrees were void where rendered and, of course, not entitled to full faith and credit in other states.

5s AMIERICAN LAW INST., RESTATEMIENT OF CONFLict OF Laws, No. 2 (1926) § 115. Grubel v. Nassauer, 210 N. Y. 149, 103 N. E. 1113 (1013), would seem to be authority for the application of a similar principle to the exercise by a foreign court of jurisdiction to render a personal judgment against a subject of the foreign state.

56 In MrcDonald v. MIabee, 243 U. S. 90, 37 Sup. Ct. 343 (1917), it vas held that publication was not a sufficient service in an action in personam against one domiciled within the state but absent therefrom, even though there was jurisdiction. 
where the other party to the relationship may acquire a domicile, we may well require notice to be given. There would probably be no disagreement from the proposition that publication of summons, as ordinarily made, results in no notice to anyone. With this restriction on the exercise of jurisdiction, which has been voluntarily adopted in some states, the most serious objection to divorce in a state where only one party is domiciled would be eliminated. Then we might reasonably expect that all states might be willing to apply to the recognition of foreign divorces the same jurisdictional tests they apply to their own power to grant divorce and thereby the number of anomalous situations of marital relations changing as parties crossed state lines would be reduced to a minimum. 